\title{
Association between non-typhoidal Salmonella isolated from commercial poultry sheds and associated factors in Paraná, Brazil: Cross-sectional retrospective study
}

\author{
Nayara Dias da Silva 1,* (1) https://orcid.org/0000-0002-1943-4779 \\ Ellen Elizabeth Laurindo² (D) https://orcid.org/0000-0003-1255-1347 \\ Camila Marinelli Martins 3,4 (D) https://orcid.org/0000-0002-8425-5769 \\ Ricardo Michael Pinheiro Silveira ${ }^{5}$ (D) https://orcid.org/0000-0002-5664-7079 \\ Claudinei Taborda da Silveira5 (D) https://orcid.org/0000-0001-6289-6306 \\ Elizabeth Santin' (D) https://orcid.org/0000-0003-3110-0875 \\ 1. Universidade Federal do Paraná - Câmpus de Ciências Agrárias - Departamento de Medicina Veterinária - Curitiba (PR), Brazil. \\ 2. Ministério da Agricultura, Pecuária e Abastecimento - Departamento de Promoção Comercial e Investimentos - Brasília (DF), \\ Brazil. \\ 3. Universidade Estadual de Ponta Grossa - Câmpus Uvaranas - Departamento de Enfermagem e Saúde Pública - Ponta Grossa (PR), \\ Brazil. \\ 4. AAC\&T Consultoria em Pesquisa - Diretoria de Pesquisa - Curitiba (PR), Brazil. \\ 5. Universidade Federal do Paraná - Câmpus Centro Politécnico - Departamento de Geografia - Curitiba (PR), Brazil. \\ *Corresponding author: sdiasnay@gmail.com
}

\begin{abstract}
The epidemiology of salmonellosis in poultry is complex, which makes it difficult to identify the origin and spread of this disease in poultry farms. The aims of this study were to characterize the spatial distribution of Salmonella enterica in epidemiological units in Paraná, Brazil; and to investigate correlations between this microorganism and associated factors. Among the epidemiological units, 78 of 243 (32.10\%) were positive. Spatially, the northwestern and western regions had higher concentrations of positive cases than the other regions. In bivariate analyses, the presence of other animal species in the epidemiological unit (prevalence ratio, $\mathrm{PR}=0.64 ; 95 \%$ confidence interval, $\mathrm{Cl}=0.43-0.95 ; \mathrm{p}=0.022)$ and proximity to establishments at risk $(\mathrm{PR}=0.51$; $95 \% \mathrm{Cl}=0.32-0.81 ; \mathrm{p}=0.001$ ) did not influence positivity, but the average population per poultry shed (between 30,501 and 32,$500 ; \mathrm{PR}=2.57 ; 95 \% \mathrm{Cl}=1.72-3.83 ; \mathrm{p}=0.001$ ) was associated with Salmonella positivity. Multiple logistic regression demonstrated that the average population per poultry shed, presence of surrounding risk-posing establishments and presence of surrounding poultry sheds produced a significant multiple model for S. enterica. The results indicated that the presence of S. enterica may be related to higher density broiler in poultry sheds, presence of surrounding poultry sheds, proximity between positive and negative epidemiological units and altitude of the municipality. The information obtained showed that some factors were related to positivity for this microorganism and emphasizes the importance of serotyping to obtain other epidemiological data.
\end{abstract}

Keywords: geographical distribution; density; distance; altitude; serovars, legislation.

\section{INTRODUCTION}

Brazil is prominent within the poultry industry, as the second largest producer and the largest exporter of chicken meat in the world. In 2019, the total production of this protein was 13,245 million tonnes and $32 \%$ of this quantity were exported. The Brazilian poultry industry is concentrated in the southern states of the country: Paraná is the largest producer (34.69\%), followed by Santa Catarina (15.40\%) and Rio Grande do Sul (14.32\%). In 2019, Paraná was also responsible for $39.13 \%$ of Brazilian exports (ABPA, 2020). To ensure food safety and quality, continuous improvement in

Received: Jul 27, 2020. Accepted: Oct 29, 2021

Associate Editor: Silvia Galleti

Peer Review History: Double-blind Peer Review. 
all sectors of the production chain is required, including poultry farm management, nutrition and biosecurity, and control over important pathogens within poultry and public health, such as Salmonella (PULIDO-LANDÍNEZ, 2019).

The genus Salmonella belongs to the family Enterobacteriaceae and comprises the species Salmonella enterica and Salmonella bongori (BRENNER et al., 2000), which have more than 2,600 known serotypes (EFSA; ECDC, 2014). Most of the pathogenic serovars of Salmonella spp. belong to the species $S$. enterica. They are commonly named based on the geographical location or the animal species from which they were isolated. Salmonella serotyping is important because it allows the identification of more pathogenic serovars and assessment of epidemiological factors that may assist in controlling these agents in poultry production (GRIMONT; WEILL, 2007). Two of these serovars are bird specific and are responsible for causing pullorum disease (S. enterica subsp. enterica serovar Pullorum) and fowl typhoid (S. enterica subsp. enterica serovar Gallinarum), which lead to occurrences of diarrhea and septicemia and high mortality rates (BARROW; FREITAS NETO, 2011). Nontyphoidal Salmonella strains are represented by any serotype of the genus, except $S$. Pullorum and $S$. Gallinarum. Most nontyphoidal Salmonella serovars do not significantly affect the zootechnical performance of poultry because they do not cause any symptoms in the host (GAST; BENSON, 1995). However, they are able to colonize the intestine and can reach the bloodstream. Thus, they can be identified in other organs such as the spleen, liver and ovaries (HUMPHREY, 2004; SHIVAPRASAD et al., 1990). Nontyphoidal Salmonella strains are able to colonize the intestinal tract, contaminate chicken carcasses at the time of slaughter and cause harm to consumer health (VOSS-RECH et al., 2015).

In 1994, an official program for controlling Salmonella in Brazilian poultry was implemented through Ordinance 193 of the Ministério da Agricultura, Pecuária e Abastecimento (MAPA) (BRAZIL, 1994). This ordinance constituted the Programa Nacional de Sanidade Avícola (PNSA), with the objective of establishing control and eradicate methodologies for the main diseases that affect poultry, including salmonellosis. The nontyphoidal Salmonella serotypes involved in this program were S. enterica subsp. enterica serovar Enteritidis and S. enterica subsp. enterica serovar Typhimurium (BRAZIL, 2003): these are pathogens of great importance for public health worldwide. Other regulations relating to Salmonella monitoring have included Normative Instructions No. 10 of April 11, 2013 (BRAZIL, 2013), and No. 20 of October 21, 2016 (BRAZIL, 2016), which were established by MAPA and refer to epidemiological surveillance within the poultry production. Given the complex epidemiology of Salmonella, other important serovars, such as Minnesota, Infantis, Heidelberg, Senftenberg and Mbandaka, have been isolated from poultry shed samples in Brazil (VOSS-RECH et al., 2015). Another study conducted in the state of Paraná showed that among 342 swab specimens processed, $S$. Heidelberg was the one most frequently isolated (12.82\%), followed by $S$. Mbandaka and $S$. Newport, which accounted for 10.25\%. Salmonella Schwarzengrund, Enteritidis and Orion each presented frequencies of 7.70\% (PANDINI et al., 2015). Preliminary data from 2018 from the Centers for Disease Control and Prevention (CDC) Foodborne Diseases Active Surveillance Network (FoodNet) showed that, among the cases of foodborne illnesses, Salmonella had the second highest incidence (18.3 cases per 100,000 population), which was only behind Campylobacter (19.5). Among the 7,013 (87\%) serotyped Salmonella isolates, the three most common were Enteritidis (2.6 per 100,000 population), Newport (1.6) and Typhimurium (1.5) (TACK et al., 2019). In the European Union in 2017, 91,662 human salmonellosis cases were confirmed and the reporting rate for human salmonellosis was 19.7 cases per 100,000 inhabitants. The most frequent serovars were $S$. Enteritidis, $S$. Typhimurium and monophasic $S$. Typhimurium. Food and animal data showed that $S$. Enteritidis was associated mainly with laying hens and chicken meat (EFSA; ECDC, 2018).

Bacteria of the genus Salmonella are widely distributed in nature and can affect different reservoirs. They are extremely resistant and can survive in different types of environments. These characteristics make them easily propagated and difficult to control (EFSA; ECDC, 2014). Salmonella is commonly found in production animals, in the intestines of pigs, poultry and cattle, but can also be present in domestic animals such as dogs, cats, birds and reptiles. The isolation of this microorganism in animal production facilities is common and, therefore, it is also commonly present in foods of animal origin (DERACHE et al., 2009). One of the main risk factors associated with $S$. enterica infection in poultry farms is animal density (ELGROUD et al., 2009), since the excretion of bacteria can infect the whole batch and even nearby batches without apparent clinical signs (PEREIRA et al., 1999). The presence of other animals in addition to poultry may also represent a risk factor for S. enterica infection in broilers (ELGROUD et al., 2009), since people transiting between breeding establishments can carry the bacteria, thus favoring agent dissemination (LE BOUQUIN et al., 2010).

A study in Brazil showed that combination of caloric stress and infection with presence of Salmonella Enteritidis can disturb the intestinal barrier of poultry, promote migration of the bacteria to other organs and cause intestinal inflammation, thus compromising productive performance (QUINTEIRO-FILHO et al., 2012). Hence, environmental factors such as temperature increase caused by changes to the weather and type of poultry housing used can alter immune system functioning and decrease the resistance to infection, thereby impairing poultry performance (QUINTEIRO-FILHO et al., 2010).

The reduction of the prevalence of Salmonella in poultry production requires detailed knowledge of the risk factors in the poultry production system (MARÍN et al., 2011). Considering the importance of salmonellosis in poultry farming and 
within public health, information relating to the epidemiology of these bacteria is important for understanding the evolution of these microorganisms and other particularities, and, thus, for enabling the development of new control methodologies. In this context, this study aimed to characterize the epidemiological profile of nontyphoidal Salmonella isolates in broilers in the state of Paraná, southern Brazil.

\section{MATERIALS AND METHODS}

\section{Data collection}

Data were provided by the Official Veterinary Service (OVS) of the state of Paraná, based on information/reports from visits and collections conducted in unregistered epidemiological units with low biosafety, which are present in the region studied. Unregistered epidemiological units are those that do not meet the minimum biosafety requirements established through Ordinance No. 290 of November 9, 2017 of the Animal Health Protection System of the Agência de Defesa Agropecuária do Paraná (ADAPAR) (PARANÁ, 2017) and Normative Instruction No. 56 of December 4, 2007 of MAPA of Brazil (BRAZIL, 2007). These requirements include management, location and isolation of facilities; physical and natural barriers; access and traffic flow control; water and feed care; poultry health program; personal training plan; contingency plan; and pest control program, among other factors. The OVS does not have data available on registered epidemiological units. When samples were collected, only unregistered epidemiological units were evaluated.

By definition, an epidemiological unit is a physical unit of poultry production, composed of one or more poultry sheds that house a group of birds of the same species and age. These units are under common production management and must be isolated from other poultry production activities through natural or artificial physical barriers and must not have structures and activities that are outside the production process, such as homes, vehicles, plantations or other creations within them. In laying hen establishments, concomitant presence of birds of the same species at different ages is permitted.

\section{Sample collection for Salmonella analysis}

All the parameters/procedures used in visits were in compliance with Normative Instructions No. 56 of December 4, 2007 (BRAZIL, 2007), No. 10 of April 11, 2013 (BRAZIL, 2013) and No. 20 of October 21, 2016 (BRAZIL, 2016) from MAPA, Brazil. Most of the data provided did not include serotyping of Salmonella; therefore, this study opted to analyze only the presence or absence of this microorganism without considering the serovars. This study on S. enterica in broilers in Paraná (visit and collection) was developed between January 2017 and May 2018, in the municipalities where the epidemiological units were located. In total, 243 unregistered epidemiological units were analyzed. This study focused on broilers.

The management sample collection procedure was conducted under the responsibility of the veterinarian of the poultry establishment, and appropriate biosecurity practices were adopted. The samples were sent to accredited laboratories. The samples each comprised four drag swabs, divided into two pools containing two drag swabs that were moistened with conservation medium. It was envisaged that these would be used to sample up to $50 \%$ of the surface of the shed chicken. The person responsible for sample collection walked the entire length of the poultry shed with the drag swabs. These comprised sterile disposable socks moistened with conservation medium. This methodology was in accordance with Normative Instruction No. 20 of October 21, 2016, of the Ministry of Agriculture, Livestock and Supply (BRAZIL, 2016).

After collection, the samples were packaged and sent as soon as possible to the laboratory. The humidity was maintained and the temperature was kept between 2 and $8^{\circ} \mathrm{C}$, with a variation of $1{ }^{\circ} \mathrm{C}$ upwards or downwards. The samples were sent to the laboratory bearing tamper-proof numbered seals, with a collection form containing identification information relating to the poultry establishment. At the time of sample collection, the birds needed to be free from any effect of antimicrobials for gram-negative bacteria, and free from any influence from products with antimicrobial action in the environment (BRAZIL, 2016).

In establishments that had one to three poultry sheds, all of them were monitored. In those with four poultry sheds, three were monitored. In those with five to ten poultry sheds, four were monitored; and in those with over 11 poultry sheds, five were monitored. The legislation stipulates that samples should be collected as close as possible to the date of poultry batch slaughter, while allowing the results to be known before slaughter. In addition, in poultry sheds that are to be sampled, those with birds that present any clinical signs, those with low zootechnical index and those with birds subjected to situations of stress periods, among other factors that favor pathogen detection, should be prioritized. It also stipulates 
that random collections may be performed at any time, and that the number and type of samples to be collected and the number of sheds to be sampled can be increased, based on epidemiological investigations (BRAZIL, 2016).

\section{Salmonella isolation, identification and serotyping}

The MAPA-recommended isolation technique was used (SÃO PAULO, 1995). The drag swabs were homogenized, and $2 \mathrm{~g}$ of the material was inoculated in $20 \mathrm{~mL}$ of brain heart infusion (BHI) broth and incubated at 35 to $37^{\circ} \mathrm{C}$ for 18 to $24 \mathrm{~h}$ (pre-enrichment). In the selective enrichment stage, the samples were homogenized, and $2 \mathrm{~g}$ of the material were inoculated into $20 \mathrm{~mL}$ of tetrathionate broth and $0.2 \mathrm{~g}$ into $20 \mathrm{~mL}$ of Rappaport-Vassiliadis broth and incubated at 42 to $43^{\circ} \mathrm{C}$ for 18 to $24 \mathrm{~h}$. In the isolation phase, Hektoen agar and bright green agar plates were striated from the pre-enrichment and selective enrichment broths and incubated at 35 to $37^{\circ} \mathrm{C}$ for 18 to $24 \mathrm{~h}$. After incubation, the colonies' appearance that had developed on the plates were observed (Hektoen agar showing blue-green colonies with or without a black center; and bright green agar showing pink colonies). To make a preliminary biochemical identification from agar, two to three colonies with Salmonella characteristics in the triple sugar iron (TSI), lysine iron (LIA), sulfide indole motility (SIM) and urea broth were picked from each plate. Strains that presented a biochemical profile compatible with Salmonella were antigenically characterized through the rapid agglutination test with somatic and flagellar antiserum. Considering that the poultry establishments in this study were unregistered, the legislation determines that all laboratory tests must be carried out in laboratories accredited to the national network of agricultural laboratories. In accordance with this legislation, epidemiological units were considered positive when at least one poultry shed had a positive diagnosis (BRAZIL, 2016).

\section{Epidemiological data}

Epidemiological information was collected by ADAPAR. The broilers were housed in screened commercial poultry sheds, but no information on lineage, age, sanitary status and vaccination was provided. The data collected were as follows: (1) type of exploitation (only broiler establishments were selected by the system); (2) poultry density (the system provided the number of birds housed in each epidemiological unit and in the surrounding units); and (3) presence of other animal species (pigs, dairy cattle, beef cattle, horses, dogs, fish, cats, sheep, goats, mules, birds reared for consumption by people at the establishment and donkeys) outside the commercial poultry sheds, in order to identify any associations between these factors and the presence of $S$. enterica. Birds reared for consumption by people at the establishment comprised those of low productivity that were kept free-range at the establishment and were unrelated to industrial production (these could be broilers or laying hens). The poultry density in the epidemiological unit was determined from the number of poultry sheds, housing capacity and average number of birds housed per poultry shed; and on other poultry farms in the area according to the number of poultry shed, breeding birds, hatching eggs, broilers and laying hens. Considering that most of the epidemiological units were located within a surrounding $5 \mathrm{~km}$ radius, this was adopted in other analyses of this study as a starting point.

\section{Spatial analysis}

In the ADAPAR system, the geographical coordinates of the epidemiological units were obtained from the point that formed the entrance to the establishment. Taking into account that the epidemiological units were considered positive when at least one poultry shed was positive, the official geographical coordinates of the establishment available in the system were used, rather than those of each poultry shed. This information was added to the database of the epidemiological variables, which made it possible to include this information in thematic maps. The maps were compiled using the ArcGIS software, version 10.5.1 (ESRI, 2017).

The analysis on distances had three aspects: distances between positive and negative epidemiological units; distances between epidemiological units and the town hall of the municipality and distances between epidemiological units and rivers and highways. For this, the means, minimums and maximums of the data were used, and these parameters were also subjected to statistical analysis for pairs of groups independently. In order to obtain the distances between epidemiological units, the nearest negative or positive point was considered, which also enabled the identification of transmissibility (positive to negative) and vulnerability (negative to positive) potentials.

The human development index (HDI) of the municipality was obtained (CHEDIEK et al., 2013). Environmental factors (temperature and precipitation) (AGRITEMPO, 2019) were evaluated in relation to the months in which samples for Salmonella investigation were collected. The average altitude of the regions studied (SILVEIRA, C.; SILVEIRA, R., 2017) 
were obtained through the mean and standard deviation data from the municipalities. Statistical analysis was performed for pairs of independent groups.

\section{Statistical analysis}

A database was compiled from information collected through the ADAPAR system and through geoprocessing analyses. The variables analyzed were divided into two groups, as follows:

The first one is the associated factors: Presence/absence of other animals, i.e., other species present in the same epidemiological unit, but not necessarily in the commercial poultry sheds where the birds are housed. These animals circulate freely around the establishment, thus enabling dispersion of the agent, even though there is no real contact between commercial broilers and other species in the epidemiological unit. These animals may include pigs, dairy cattle, beef cattle, horses, dogs, fish, cats, sheep, goats, mules, birds (that are kept for consumption by people at the establishment) and donkeys.

Presence/absence of risk-posing establishments, i.e., establishments relating to rearing, slaughtering or industrial processing of birds and other animal species, along with small businesses that can carry the agent through vehicles and people transiting nearby, within the surrounding $5 \mathrm{~km}$. These can include the following: farming stores (agricultural supply stores that can trade live birds), cattle slaughterhouses, poultry slaughterhouses, cold-storage warehouses (where meat is processed and stored after slaughter), agro-industrial cooperatives (free-membership organizations that contribute to their members' evolution in the economic and social spheres), fish producers and traders, dairies, animal protection societies, poultry integration companies (i.e., suppliers of one-day-old chicks, feed, technical assistance, medicines, housing support and air conditioning), supermarkets (which may contain products of animal origin without proper veterinary inspection) and smallholdings (small farms unrelated to cooperatives or poultry integration).

Poultry density variables, i.e., the total capacity of housing, number of poultry sheds and average number of birds housed per poultry shed in the epidemiological unit, and the poultry density in the surroundings. These were categorized and incorporated as categorical variables in the regression model. The data were categorized based on the most common categories of bird housing in the state of Paraná.

The prevalence ratio (PR) was used as a measurement of associations in bivariate analyses and the logistic regression model was used in multiple analyses. These multiple analyses with logistic regression models were performed with positive/ negative epidemiological units as the dependent variable and the associated factors as independent variables. The method used to select models was stepwise. The model processing was started using a cutoff of $\mathrm{p}<0.20$ in bivariate analysis. Subsequently, to choose a better multiple model, $\mathrm{p}$-values $<0.05$ were used for each independent variable, $r$-square adjustments and interactions between independent variables as controls for confounding. The interpretation of the final models was based on the adjusted PR. The intensity of the association between the presence of disease and presence/absence of associated factors relating to presence of other animals, proximity to risk-posing establishments and poultry density was assessed using the PR and its corresponding confidence interval. The PR demonstrated the strength of association among poultry exposed to the study factor (disease) and how many times more likely it was that exposed birds would have the disease/ condition than would unexposed birds (OLIVEIRA et al., 1997).

The second group is associated spatial variables: these comprised the distance between positive epidemiological units, distance between epidemiological units and highways, rivers and the town hall of the municipality (kilometers), municipal HDI (very low, low, medium, high or very high), mean monthly temperature $\left({ }^{\circ} \mathrm{C}\right)$, the mean monthly precipitation (millimeters) and altitude (meters). In these analyses, the data were subjected to a normal distribution test. Student's $t$ test was applied to parametric variables and the Mann-Whitney test to nonparametric variables. The results were interpreted considering a significance level of 5\%. The data were also subjected to descriptive analysis to calculate means and frequencies.

The analyses were done with the aid of R environmental software (R CORE TEAM, 2019), through the "epitools" package (ARAGON, 2020), and IBM SPSS software, version 21 (IBM CORP, 2012).

\section{RESULTS}

\section{General aspects}

In Paraná, there are 399 municipalities with 10,804 epidemiological units and 18,974 poultry sheds, distributed across $81.20 \%$ of the state, including both the registered and unregistered units. In total, 243 unregistered epidemiological units 
in 60 municipalities were analyzed, i.e., $2.25 \%$ of the total number of epidemiological units in the state. It was verified that, among the epidemiological units studied, 78 (32.10\%) were positive. The map shown in Figure 1 highlights two regions in which positive cases were concentrated, in the northwest and west of the state.

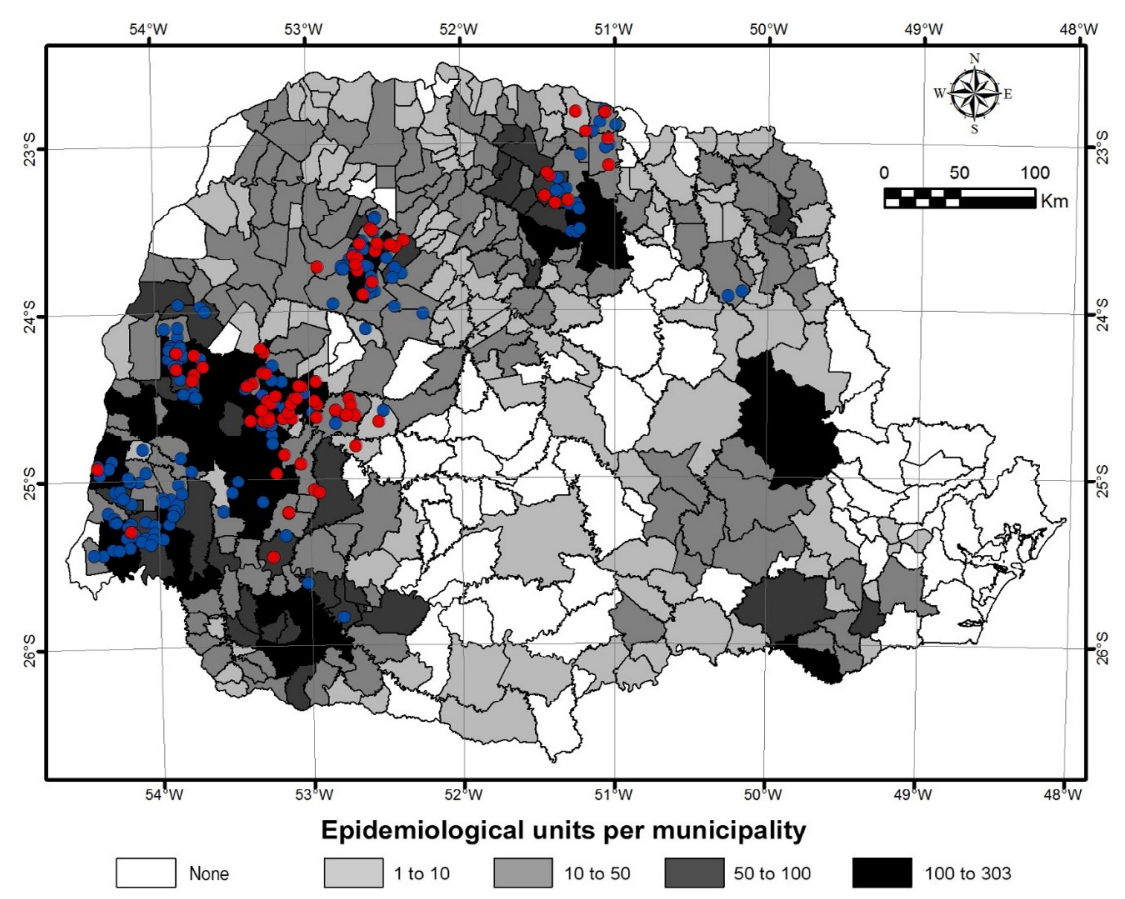

Distribution of epidemiological units that were positive and negative for Salmonella enterica

Positive

Negative

Figure 1. The distribution of epidemiological units that were positive and negative for Salmonella enterica, overlain on poultry density data for the state of Paraná.

Source: Elaborated by the authors.

\section{Associated factor analysis for Salmonella infection: contact with other animals}

In this study, among the epidemiological units at which other animals were present, $24.5 \%$ were positive and $75.5 \%$ negative. Among those at which no other animals were present, $38.3 \%$ were positive and $61.7 \%$ negative. Among the epidemiological units with the presence of other animals, a higher percentage was negative. Analysis on the prevalence ratios showed that there was a statistically significant protective association between Salmonella isolation and contact with other animals (prevalence ratio, $\mathrm{PR}=0.64 ; 95 \%$ confidence interval, $\mathrm{CI}=0.43-0.95 ; \mathrm{p}=0.022$ ) (Table 1 ).

Table 1. The presence of other animals in positive and negative epidemiological units.

\begin{tabular}{|c|c|c|c|c|c|}
\hline Exposure factor & Positive & Negative & Total & PR & $P$ value \\
\hline \multicolumn{6}{|l|}{ Contact with pigs } \\
\hline Yes & $10(25.0 \%)$ & $30(75.0 \%)$ & 40 (100.0\%) & \multirow{2}{*}{$0.75(0.42-1.32)$} & \multirow{2}{*}{0.293} \\
\hline No & $68(33.5 \%)$ & $135(66.5 \%)$ & $203(100.0 \%)$ & & \\
\hline \multicolumn{6}{|c|}{ Contact with dairy cattle } \\
\hline Yes & $15(24.6 \%)$ & $46(75.4 \%)$ & $61(100.0 \%)$ & \multirow{2}{*}{$0.71(0.43-1.15)$} & \multirow{2}{*}{0.147} \\
\hline No & $63(34.6 \%)$ & 119 (65.4\%) & 182 (100.0\%) & & \\
\hline \multicolumn{6}{|c|}{ Contact with beef cattle } \\
\hline Yes & $21(31.8 \%)$ & $45(68.2 \%)$ & 66 (100.0\%) & \multirow{2}{*}{$0.98(0.65-1.49)$} & \multirow{2}{*}{0.954} \\
\hline No & 57 (32.2\%) & $120(67.8 \%)$ & $177(100.0 \%)$ & & \\
\hline
\end{tabular}


Table 1. Continuation...

\begin{tabular}{|c|c|c|c|c|c|}
\hline Exposure factor & Positive & Negative & Total & PR & $P$ value \\
\hline \multicolumn{6}{|c|}{ Contact with horses } \\
\hline Yes & $5(23.8 \%)$ & $16(76.2 \%)$ & $21(100.0 \%)$ & \multirow{2}{*}{$0.72(0.33-1.59)$} & \multirow{2}{*}{0.395} \\
\hline No & 73 (32.9\%) & $149(67.1 \%)$ & 222 (100.0\%) & & \\
\hline \multicolumn{6}{|l|}{ Contact with dogs } \\
\hline Yes & $3(20.0 \%)$ & 12 (80.0\%) & $15(100.0 \%)$ & \multirow{2}{*}{$0.61(0.22-1.70)$} & \multirow{2}{*}{0.300} \\
\hline No & 75 (32.9\%) & $153(67.1 \%)$ & $228(100.0 \%)$ & & \\
\hline \multicolumn{6}{|l|}{ Contact with fish } \\
\hline Yes & $2(14.3 \%)$ & $12(85.7 \%)$ & $14(100.0 \%)$ & \multirow{2}{*}{$0.43(0.12-1.57)$} & \multirow{2}{*}{0.141} \\
\hline No & $76(33.2 \%)$ & 153 (66.8\%) & 229 (100.0\%) & & \\
\hline \multicolumn{6}{|l|}{ Contact with cats } \\
\hline Yes & $2(25.0 \%)$ & $6(75.0 \%)$ & $8(100.0 \%)$ & \multirow{2}{*}{$0.77(0.23-2.60)$} & \multirow{2}{*}{0.661} \\
\hline No & $76(32.3 \%)$ & $159(67.7 \%)$ & 235 (100.0\%) & & \\
\hline \multicolumn{6}{|c|}{ Contact with sheep } \\
\hline Yes & $2(25.0 \%)$ & $6(75.0 \%)$ & $8(100.0 \%)$ & \multirow{2}{*}{$0.77(0.23-2.60)$} & \multirow{2}{*}{0.662} \\
\hline No & $76(32.3 \%)$ & $159(67.7 \%)$ & 235 (100.0\%) & & \\
\hline \multicolumn{6}{|c|}{ Contact with goats } \\
\hline Yes & $2(40.0 \%)$ & $3(60.0 \%)$ & $5(100.0 \%)$ & \multirow{2}{*}{$1.25(0.42-3.72)$} & \multirow{2}{*}{0.702} \\
\hline No & 76 (31.9\%) & $162(68.1 \%)$ & 238 (100.0\%) & & \\
\hline \multicolumn{6}{|c|}{ Contact with mules } \\
\hline Yes & $0(0.0 \%)$ & $1(100.0 \%)$ & $1(100.0 \%)$ & \multirow{2}{*}{ * } & \multirow{2}{*}{0.490} \\
\hline No & $78(32.2 \%)$ & $164(67.8 \%)$ & 242 (100.0\%) & & \\
\hline \multicolumn{6}{|c|}{ Contact with birds for consumption by people at the unit } \\
\hline Yes & $0(0.0 \%)$ & $1(100.0 \%)$ & $1(100.0 \%)$ & \multirow{2}{*}{ * } & \multirow{2}{*}{0.490} \\
\hline No & $78(32.25 \%)$ & $164(67.8 \%)$ & $242(100.0 \%)$ & & \\
\hline \multicolumn{6}{|c|}{ Contact with donkeys } \\
\hline Yes & $1(100.0 \%)$ & $0(0.0 \%)$ & $1(100.0 \%)$ & \multirow{2}{*}{$3.14(2.61-3.78)$} & \multirow{2}{*}{0.145} \\
\hline No & $77(31.8 \%)$ & $165(68.2 \%)$ & $242(100.0 \%)$ & & \\
\hline \multicolumn{6}{|c|}{ Presence/absence of other animals } \\
\hline Presence & $27(24.5 \%)$ & $83(75.5 \%)$ & $110(100.0 \%)$ & \multirow{2}{*}{$0.64(0.43-0.95)$} & \multirow{2}{*}{0.022} \\
\hline Absence & $51(38.3 \%)$ & $82(61.7 \%)$ & $133(100.0 \%)$ & & \\
\hline
\end{tabular}

*Prevalence ratio could not be calculated.

Source: Elaborated by the authors.

\section{Associated factor analysis for Salmonella infection: proximity of risk-posing establishments}

In this study, among epidemiological units located within $5 \mathrm{~km}$ of risk-posing establishments, $20 \%$ were positive and $80 \%$ negative. Among those that were not close to these establishments, $39.2 \%$ were positive and $60.8 \%$ negative. Thus, a high percentage of epidemiological units near risk-posing places was negative and the prevalence ratio confirmed that there was a statistically significant protective association between Salmonella isolation and proximity to these sites $(\mathrm{PR}=0.51 ; 95 \% \mathrm{CI}=0.32-0.81 ; \mathrm{p}=0.001)$. Similarly, there was a statistically significant association with the presence of agro-industrial cooperatives in the surroundings, but for protection $(\mathrm{PR}=0.41 ; 95 \% \mathrm{CI}=0.18-0.93$; $\mathrm{p}=0.015)($ Table 2). 
Table 2. Proximity to risk-posing establishments within $5 \mathrm{~km}$ of epidemiological units that were positive and negative for Salmonella enterica.

\begin{tabular}{|c|c|c|c|c|c|}
\hline Exposure factor & Positive & Negative & Total & PR & $P$ value \\
\hline \multicolumn{6}{|l|}{ Farming store } \\
\hline Yes & $12(22.2 \%)$ & $42(77.8 \%)$ & $54(100.0 \%)$ & \multirow{2}{*}{$0.64(0.37-1.09)$} & \multirow{2}{*}{0.078} \\
\hline No & $66(3.9 \%)$ & $123(65.1 \%)$ & $189(100.0 \%)$ & & \\
\hline \multicolumn{6}{|c|}{ Cattle slaughterhouse } \\
\hline Yes & $1(25.0 \%)$ & $3(75.0 \%)$ & $4(100.0 \%)$ & \multirow{2}{*}{$0.77(0.14-4.28)$} & \multirow{2}{*}{0.759} \\
\hline No & $77(32.2 \%)$ & $162(67.8 \%)$ & 239 (100.0\%) & & \\
\hline \multicolumn{6}{|l|}{$\begin{array}{l}\text { Poultry } \\
\text { slaughterhouse }\end{array}$} \\
\hline Yes & $2(50.0 \%)$ & $2(50.0 \%)$ & $4(100.0 \%)$ & \multirow{2}{*}{$1.57(0.58-4.26)$} & \multirow{2}{*}{0.439} \\
\hline No & $76(31.8 \%)$ & $163(68.2 \%)$ & $239(100.0 \%)$ & & \\
\hline \multicolumn{6}{|c|}{ Cold-storage facility } \\
\hline Yes & $\mathrm{O}(0.0 \%)$ & 15 (100.0\%) & 15 (100.0\%) & \multirow{2}{*}{ * } & \multirow{2}{*}{0.006} \\
\hline No & $78(34.2 \%)$ & $150(65.8 \%)$ & 228 (100.0\%) & & \\
\hline \multicolumn{6}{|c|}{ Agro-industrial cooperative } \\
\hline Yes & $5(14.3 \%)$ & $30(85.7 \%)$ & 35 (100.0\%) & \multirow{2}{*}{$0.41(0.18-0.93)$} & \multirow{2}{*}{0.015} \\
\hline No & $73(35.1 \%)$ & 135 (64.9\%) & $208(100.0 \%)$ & & \\
\hline \multicolumn{6}{|c|}{ Fish production or trading } \\
\hline Yes & $1(20.0 \%)$ & 4 (80.0\%) & 5 (100.0\%) & \multirow{2}{*}{$0.62(0.11-3.60)$} & \multirow{2}{*}{0.558} \\
\hline No & 77 (32.4\%) & $161(67.6 \%)$ & $238(100.0 \%)$ & & \\
\hline \multicolumn{6}{|l|}{ Dairy } \\
\hline Yes & 7 (28.0\%) & $18(72.0 \%)$ & 25 (100.0\%) & \multirow{2}{*}{$0.86(0.44-1.66)$} & \multirow{2}{*}{0.643} \\
\hline No & $71(32.6 \%)$ & $147(67.4 \%)$ & $218(100.0 \%)$ & & \\
\hline \multicolumn{6}{|c|}{ Animal protection society } \\
\hline Yes & $\mathrm{O}(0.0 \%)$ & $1(100.0 \%)$ & $1(100.0 \%)$ & \multirow{2}{*}{ * } & \multirow{2}{*}{0.491} \\
\hline No & $78(32.2 \%)$ & $164(67.8 \%)$ & 242 (100.0\%) & & \\
\hline \multicolumn{6}{|c|}{ Poultry integration company } \\
\hline Yes & $1(16.7 \%)$ & $5(83.3 \%)$ & $6(100.0 \%)$ & \multirow{2}{*}{$0.51(0.08-3.10)$} & 0112 \\
\hline No & $77(32.5 \%)$ & $160(67.5 \%)$ & $237(100.0 \%)$ & & 0.412 \\
\hline Supermarket & & & & & \\
\hline Yes & $0(0.0 \%)$ & $5(100.0 \%)$ & $5(100.0 \%)$ & * & 0120 \\
\hline No & 78 (32.8\%) & $160(67.2 \%)$ & $238(100.0 \%)$ & & $0.1<0$ \\
\hline Individual farm & & & & & \\
\hline Yes & $0(0.0 \%)$ & 1 (100.0\%) & 1 (100.0\%) & * & 0101 \\
\hline No & $78(32.2 \%)$ & $164(67.8 \%)$ & $242(100.0 \%)$ & & 0.491 \\
\hline Slaughterhouse & Id-storage fac & & & & \\
\hline Yes & $1(33.3 \%)$ & $2(66.7 \%)$ & $3(100.0 \%)$ & $101(021-520)$ & 0963 \\
\hline No & $77(32.1 \%)$ & $163(67.9 \%)$ & 240 (100.0\%) & $1.04(0.21-0.20)$ & כ \\
\hline Presence/absen & isk-posing es & ments & & & \\
\hline Presence & $18(20.0 \%)$ & $72(80.0 \%)$ & 90 (100.0\%) & & \\
\hline Absence & $60(39.2 \%)$ & $93(60.8 \%)$ & $153(100.0 \%)$ & $0.51(0.52-0.01)$ & 0.001 \\
\hline
\end{tabular}

*Prevalence ratio could not be calculated.

Source: Elaborated by the authors. 


\section{Associated factor analysis for Salmonella infection: poultry density in the epidemiological unit}

Table 3 shows the parameters of the number of poultry sheds, housing capacity and average number of birds per poultry shed for both positive and negative epidemiological units. The poultry density around the epidemiological units (poultry shed, breeding birds, hatching eggs, laying hens and broilers) was also analyzed.

Table 3. Poultry density within $5 \mathrm{~km}$ of epidemiological units that were positive and negative for Salmonella enterica.

\begin{tabular}{|c|c|c|c|c|c|}
\hline Exposure factor & Positive & Negative & Total & PR & $P$ value \\
\hline \multicolumn{6}{|c|}{ Number of poultry sheds } \\
\hline$\leq 2$ & $63(31.0 \%)$ & $140(69.0 \%)$ & 203 (100.0\%) & Ref. & \\
\hline $3-5$ & $14(38.9 \%)$ & $22(61.1 \%)$ & $36(100.0 \%)$ & $1.25(0.79-1.98)$ & 0.353 \\
\hline$>5$ & $1(25.0 \%)$ & $3(75.0 \%)$ & $4(100.0 \%)$ & $0.80(0.14-4.45)$ & 0.796 \\
\hline \multicolumn{6}{|l|}{ Total housing capacity } \\
\hline$\leq 30,000$ & $28(25.0 \%)$ & $84(75.0 \%)$ & $112(100.0 \%)$ & Ref. & \\
\hline $30,001-150,000$ & $49(38.3 \%)$ & 79 (61.7\%) & $128(100.0 \%)$ & $1.53(1.04-2.26)$ & 0.028 \\
\hline$>150,000$ & $1(33.3 \%)$ & $2(66.7 \%)$ & $3(100.0 \%)$ & $1.33(0.26-6.82)$ & 0.742 \\
\hline \multicolumn{6}{|c|}{ Average number of birds per poultry shed } \\
\hline$\leq 30,500$ & $54(27.8 \%)$ & $140(72.2 \%)$ & $194(100.0 \%)$ & Ref. & \\
\hline $30,501-32,500$ & $10(71.4 \%)$ & $4(28.6 \%)$ & $14(100.0 \%)$ & $2.57(1.72-3.83)$ & 0.001 \\
\hline $32,501-37,000$ & $14(42.4 \%)$ & $19(57.6 \%)$ & $33(100.0 \%)$ & $1.52(0.96-2.41)$ & 0.091 \\
\hline$>37,000$ & $0(00.0 \%)$ & 2 (100.0\%) & $2(100.0 \%)$ & * & 0.381 \\
\hline \multicolumn{6}{|c|}{ Poultry sheds in surroundings } \\
\hline$\leq 50$ & $55(35.7 \%)$ & 99 (64.3\%) & $154(100.0 \%)$ & Ref. & \\
\hline $51-100$ & 12 (18.5\%) & $53(81.5 \%)$ & 65 (100.0\%) & $0.52(0.30-0.90)$ & 0.011 \\
\hline$>100$ & $11(45.8 \%)$ & $13(54.2 \%)$ & $24(100.0 \%)$ & $1.28(0.79-2.08)$ & 0.340 \\
\hline \multicolumn{6}{|c|}{ Breeding birds in surroundings } \\
\hline$\leq 50,000$ & $63(29.6 \%)$ & $150(70.4 \%)$ & 213 (100.0\%) & Ref. & \\
\hline $50,001-100,000$ & $5(45.5 \%)$ & $6(54.5 \%)$ & $11(100.0 \%)$ & $1.54(0.78-3.03)$ & 0.264 \\
\hline$>100,000$ & $10(52.6 \%)$ & $9(47.4 \%)$ & 19 (100.0\%) & $1.78(1.11-2.86)$ & 0.038 \\
\hline \multicolumn{6}{|c|}{ Hatching eggs in surroundings } \\
\hline$\leq 5,000,000$ & 73 (31.5\%) & 159 (68.5\%) & 232 (100.0\%) & Ref. & \\
\hline $\begin{array}{l}5,000,001- \\
10,000,000\end{array}$ & $4(44.4 \%)$ & $5(55.6 \%)$ & 9 (100.0\%) & $1.41(0.66-3.00)$ & 0.413 \\
\hline$>10,000,000$ & $1(100.0 \%)$ & $1(100.0 \%)$ & 2 (100.0\%) & $1.59(0.39-6.44)$ & 0.575 \\
\hline \multicolumn{6}{|c|}{ Broilers in surroundings } \\
\hline$\leq 500,000$ & $27(36.5 \%)$ & $47(63.5 \%)$ & $74(100.0 \%)$ & Ref. & \\
\hline $500,001-1,000,000$ & $21(29.2 \%)$ & $51(70.8 \%)$ & $72(100.0 \%)$ & $0.80(0.50-1.28)$ & 0.346 \\
\hline$>1,000,000$ & $30(30.9 \%)$ & $67(69.1 \%)$ & $97(100.0 \%)$ & $0.85(0.55-1.29)$ & 0.445 \\
\hline \multicolumn{6}{|c|}{ Laying hens in surroundings } \\
\hline$\leq 50,000$ & $75(34.1 \%)$ & 145 (65.9\%) & 220 (100.0\%) & Ref. & \\
\hline $50,001-100,000$ & O (00.0\%) & $9(100.0 \%)$ & 9 (100.0\%) & * & 0.033 \\
\hline$>100,000$ & $3(21.4 \%)$ & $11(78.6 \%)$ & $14(100.0 \%)$ & $0.63(0.23-1.74)$ & 0.330 \\
\hline
\end{tabular}

"Ref." means that the next values were calculated based on this number; * means that no calculation was possible.

Source: Elaborated by the authors. 
In both the S. enterica-positive and the negative epidemiological units, up to two poultry sheds were predominant per epidemiological unit. The total housing capacity in the negative epidemiological units was higher than that of the positive units. There was a statistically significant association between the risk of Salmonella isolation and the average housing capacity of 30,001 to 150,000 ( $\mathrm{PR}=1.53 ; 95 \% \mathrm{CI}=1.04-2.26 ; \mathrm{p}=0.028)$. The average number of birds per poultry shed was higher in positive epidemiological units and, through analyzing the prevalence ratio, it was confirmed that there was a statistically significant association between the risk of Salmonella isolation and an average number of birds per shed of $30,501-32,500(\mathrm{PR}=2.57 ; 95 \% \mathrm{CI}=1.72-3.83 ; \mathrm{p}=0.001)$. This suggests that this number of birds housed per poultry shed may increase the incidence of S. enterica.

Regarding the parameter of surrounding poultry sheds, the highest proportion was around negative epidemiological units. The category $51-100$ showed a statistically significant association with protection $(\mathrm{PR}=0.52 ; 95 \% \mathrm{CI}=0.30-0.90$; $\mathrm{p}=0.011$ ). In the analysis of breeding birds surrounding the epidemiological unit, there was a subtle difference between positive (relatively higher) and negative in the $>100,000$ category. Analysis of the prevalence ratio confirmed that there was a statistically significant association between the risk of isolation of Salmonella and this category $(\mathrm{PR}=1.78$; $95 \% \mathrm{CI}=1.11-2.86 ; \mathrm{p}=0.038$ ). The proportion of hatching eggs in the surroundings was higher in negative epidemiological units, especially in the category $\leq 5,000,000$, as also was the proportion of broilers in the category $>1,000,000$. For laying hens in the surroundings, there was a statistically significant association in the 50,001-100,000 category because there was no positive count and therefore, it was not possible to calculate the prevalence ratio.

\section{Logistic regression analysis}

Through logistic regression analysis for Salmonella, it was found that the largest associations were related to the average number of birds per poultry shed $(30,501$ to 32,500 [ref. $\leq 30,500]$ ), the surrounding establishments that posed a risk (yes [ref. no.]); and the number of surrounding poultry sheds (over 5 [ref. 0 to 2]). Considering all the variables together (contact with other animals, proximity to risk-posing establishments and poultry density), it could be seen that these factors produced a significant multiple model for Salmonella (Table 4), except for the parameter of surrounding risk-posing establishments, which remained protective even after controlling for interactions. Other binary logistic regression models were tested using variables with p-values $\leq 0.20$ in the bivariate analysis. However, these variables were excluded from the model because they did not show any $\mathrm{p}$ values $<0.05$.

Table 4. Multiple logistic regression model using the significant variables

\begin{tabular}{lcc}
\hline Significant variables* & Adjusted PR (95\% CI) & P value \\
\hline Average number of birds per poultry shed: 30,501 to 32,500 (ref. $\leq 30,500)$ & $6.93(1.02-23.81)$ & 0.002 \\
\hline Risk-posing establishments in surroundings: yes (ref. no.) & $0.42(0.22-0.79)$ & 0.007 \\
\hline Poultry sheds in surroundings: more than 5 (ref. O to 2) & $2.79(1.04-7.47)$ & 0.041 \\
\hline
\end{tabular}

*Controlled for interactions between independent variables.

Source: Elaborated by the authors.

\section{Spatial analysis}

\section{Distance analysis between epidemiological units}

Table 5 shows the distances in kilometers $(\mathrm{km})$ from positive epidemiological units to the nearest other positive unit, from positive units to the nearest negative unit and from negative units to the nearest positive unit.

In general, the smallest distance between a positive epidemiological unit and the nearest other positive one was $100 \mathrm{~m}$. Analysis of the distances between positive establishments and the nearest negative ones showed that the minimum was $130 \mathrm{~m}$ and the maximum was $36.35 \mathrm{~km}$. Thus, there was a potential for transmission from positive to negative units over small distances. Analysis of the distances from negative to positive units showed the potential vulnerability, considering that the smaller the distance to a positive epidemiological unit was, the more vulnerable to infection a negative epidemiological unit became. However, in this context, the range between the minimum and maximum distance was considerable, since the shortest distance was $130 \mathrm{~m}$ and the longest was $121.92 \mathrm{~km}$.

It was noticed that positive epidemiological units showed lower means and ranges of distances than negative units. This allows the hypothesis that the positive units had greater potential for transmission of $S$. enterica. This parameter presented a statistical difference according to the Mann-Whitney test $(\mathrm{p}<0.05)$. 
Considering only the positive epidemiological units, most of them (58.97\%) were within $5 \mathrm{~km}$ of other positive ones, while $34.62 \%$ were between 5 and $20 \mathrm{~km}$ away from each other (Fig. 2).

Table 5. General distances $(\mathrm{km})$ between the epidemiological units studied and distance analysis between positive and negative epidemiological units and between these and the town hall of the municipality, highways and rivers.

\begin{tabular}{|c|c|c|c|c|c|c|c|}
\hline $\begin{array}{l}\text { Distance to nearest } \\
\text { epidemiological unit }\end{array}$ & \multicolumn{2}{|c|}{ Minimum } & \multicolumn{2}{|c|}{ Maximum } & \multicolumn{2}{|c|}{ Mean } & $P$ value \\
\hline Positive to positive & \multicolumn{2}{|c|}{0.10} & \multicolumn{2}{|c|}{47.39} & \multicolumn{2}{|c|}{7.35} & \\
\hline Positive to negative & \multicolumn{2}{|c|}{0.13} & \multicolumn{2}{|c|}{36.35} & \multicolumn{2}{|c|}{6.83} & 0 \\
\hline Negative to positive & \multicolumn{2}{|c|}{0.13} & \multicolumn{2}{|c|}{121.92} & \multicolumn{2}{|c|}{14.84} & \\
\hline \multirow{2}{*}{ Other distances } & \multicolumn{3}{|c|}{ Positive } & \multicolumn{3}{|c|}{ Negative } & R. \\
\hline & Mean & Median & SD & Mean & Median & SD & r value \\
\hline Town hall of the municipality & 8.96 & 8.50 & 4.97 & 8.67 & 8.66 & 4.29 & $0.639 *$ \\
\hline Highways & 3.17 & 2.57 & 2.74 & 2.68 & 2.14 & 2.23 & 0.282 \\
\hline Rivers & 0.27 & 0.20 & 0.21 & 0.23 & 0.18 & 0.18 & 0.335 \\
\hline
\end{tabular}

*Student's $t$ test.

Source: Elaborated by the authors.

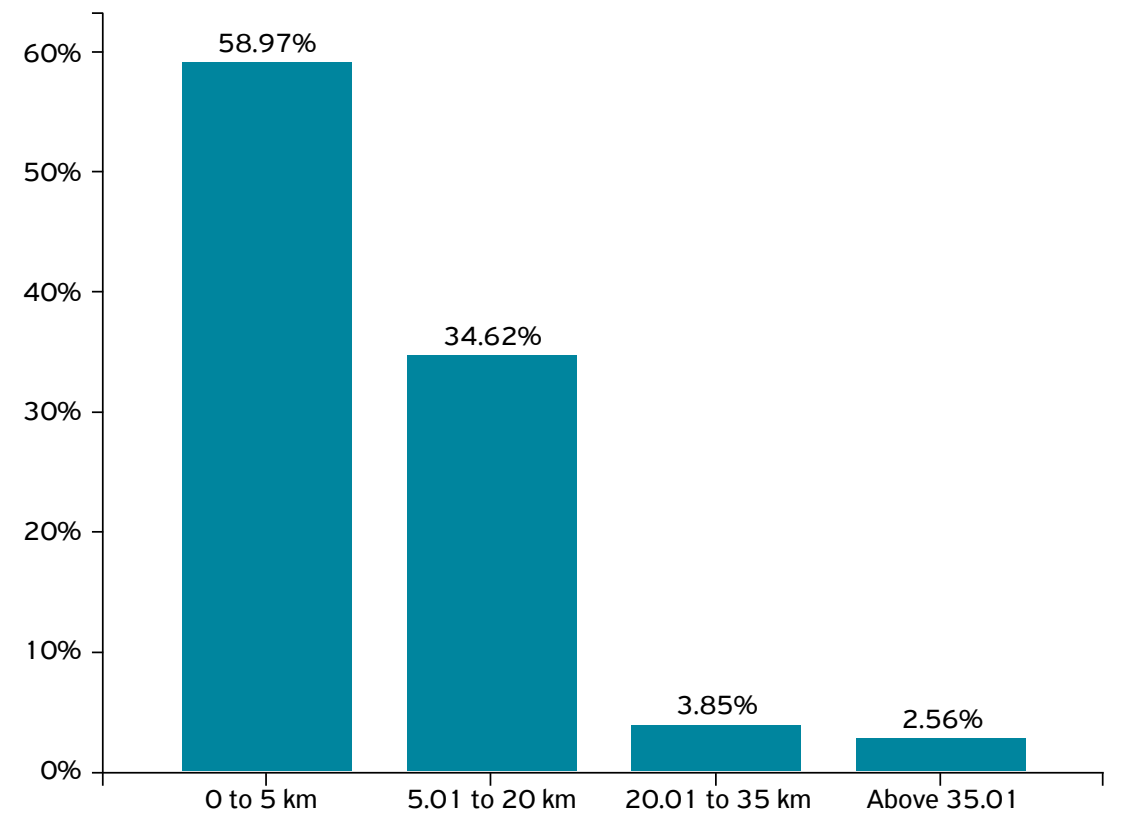

Figure 2. Distances between positive epidemiological units.

Source: Elaborated by the authors.

Distance analysis between epidemiological units, town hall of the municipality, highways and rivers

Table 5 presents distance data between the positive epidemiological units and the town hall of the municipality, highways and rivers. From this, it can be seen that there were no statistical differences regarding these parameters. This suggesting that they did not have any influence on the presence of S. enterica in this study.

\section{Analysis of the municipal HDI among the municipalities of the epidemiological units studied}

Figure 3 shows the HDI of the municipalities studied (CHEDIEK et al., 2013), with emphasis on positive and negative cases. Among these municipalities, the HDI was classified as high in $31 \%$ of the positive cases, while it was high in $69 \%$ of the negative cases. Among municipalities with average HDI, 40.7\% were positive and 59.3\% were negative. There was no statistical difference in this parameter $(\mathrm{p}>0.05)$, while the prevalence ratio indicated that high HDI was a protective factor among epidemiological units exposed to the disease (Table 6). 


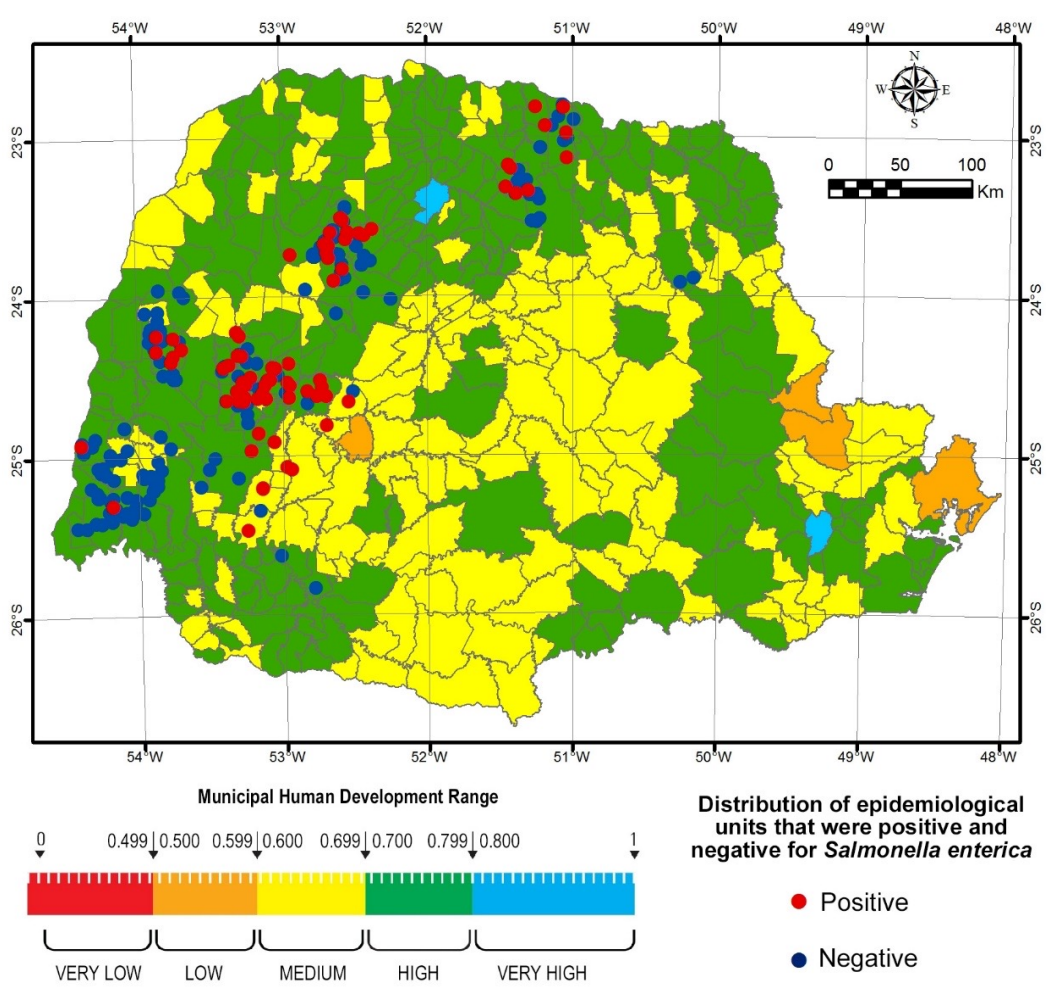

Figure 3. The municipal human development index (HDI) distribution in the state of Paraná and epidemiological units that were positive and negative for Salmonella enterica.

Source: Elaborated by the authors.

Table 6. The municipal human development index (HDI) in municipalities with epidemiological units that were positive and negative for Salmonella enterica.

\begin{tabular}{cccccc}
\hline Municipal HDI & Positive & Negative & Total & PR & P value \\
\hline Medium & $11(40.7 \%)$ & $16(59.3 \%)$ & $27(100.0 \%)$ & $0.76(0.46-1.25)$ & 0.308 \\
\hline High & $67(31.0 \%)$ & $149(69.0 \%)$ & $216(100.0 \%)$ & & \\
\hline
\end{tabular}

Source: Elaborated by the authors.

\section{Temperature $\left({ }^{\circ} \mathrm{C}\right)$ in the municipalities of the epidemiological units studied}

Table 7 shows the average monthly temperatures in the municipalities studied (AGRITEMPO, 2019), especially in the positive and negative cases. This parameter showed little variation between positive and negative cases and there was no statistical difference according to the Mann-Whitney test. This suggests that this variable was not related to S. enterica infection in this analysis.

Table 7. The temperature, precipitation and altitude distribution in the state of Paraná and epidemiological units that were positive and negative for Salmonella enterica.

\begin{tabular}{|c|c|c|c|c|c|c|c|}
\hline & \multicolumn{3}{|c|}{ Positive } & \multicolumn{3}{|c|}{ Negative } & \multirow{2}{*}{$p$ value } \\
\hline & Mean & Median & SD & Mean & Median & SD & \\
\hline Temperature & 25.14 & 25.13 & 1.51 & 25.30 & 25.23 & 1.44 & 0.593 \\
\hline Precipitation & 5.63 & 5.30 & 2.53 & 5.83 & 5.63 & 2.37 & 0.265 \\
\hline Altitude & 478.26 & 460.99 & 119.88 & 434.98 & 426.32 & 133.18 & 0.023 \\
\hline
\end{tabular}

Source: Elaborated by the authors. 


\section{Precipitation $(\mathrm{mm})$ in the municipalities of the epidemiological units studied}

Table 7 shows the precipitation in the municipalities studied (AGRITEMPO, 2019), with emphasis on positive and negative cases. This parameter showed little variation between positive and negative cases and there was no statistical difference according to the Mann-Whitney test. This suggests that this variable was not related to S. enterica infection in this study.

\section{Altitude $(m)$ in the municipalities of the epidemiological units studied}

Figure 4 and Table 7 demonstrate the altitudes of the municipalities studied (SILVEIRA, C.; SILVEIRA, R., 2017), with emphasis on positive and negative cases. In this study, it was observed that the municipalities of the epidemiological units that were positive for S. enterica were at higher altitudes than those with negative epidemiological units $(\mathrm{p}<0.05)$.

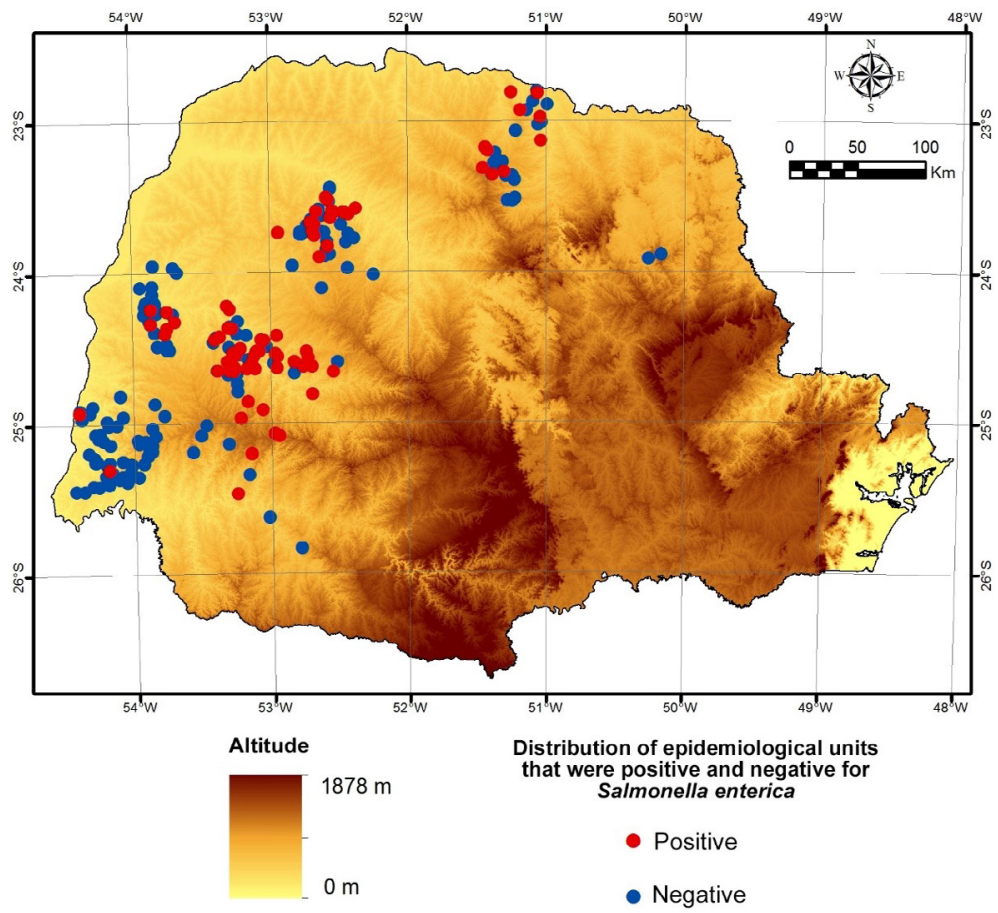

Figure 4. The altitude distribution in the state of Paraná and epidemiological units that were positive and negative for S. enterica. Source: Elaborated by the authors.

\section{DISCUSSION}

Was identified 78 positive epidemiological units among the 243 epidemiological units studied. The positivity rate was, therefore, $32.10 \%$. In another study conducted in Paraná (PANDINI et al., 2015), of 342 drag swab samples that came from epidemiological units in this state, $11.4 \%$ were positive for S. enterica. This difference in positivity can be attributed to a more careful analysis, after implementation of Normative Instruction No. 20 of October 21, 2016 (BRAZIL, 2016). The epidemiological units studied were located in municipalities predominantly in the northern, northwestern, western, southwestern and northeastern regions of Paraná (Fig. 1). It could be seen that the northwestern and western regions had higher concentrations of positive cases than the other regions studied.

The presence of animals other than poultry in poultry production establishments may also be a factor associated with S. enterica infection (ELGROUD et al., 2009) in broilers. This is because, among other factors, the traffic of people in one way or another can carry the bacteria, thus favoring dissemination of the agent in the establishment (LE BOUQUIN et al., 2010). This study demonstrated that a higher percentage of epidemiological units with the presence of other animals were negative. However, as previously reported in other studies (BOUWKNEGT et al., 2004; ELGROUD et al., 2009), it was expected that establishments with the presence of other animals would be more predisposed to positivity for pathogenic bacteria than those that did not have any other animals on the establishment. The low competitiveness of Salmonella in relation to other microorganisms may be an explanation for these findings (AHO, 1992; BARROW, 2000), which may 
therefore result in low prevalence of infection in the batch (ARNOLD et al., 2005). In addition, the birds only release S. enterica intermittently, in small quantities in their feces, which makes it difficult to detect the bacteria (BOUWKNEGT et al., 2004). From another perspective, bacterial resistance varies under adverse environmental conditions, and this may hinder isolation of S. enterica, especially with regard to assessing epidemiological units that present low biosafety, as was the case in this study. This is due to the large number of other species of bacteria in the environment (mainly lactic acid), against which Salmonella has low competitive capacity (BONI et al., 2011).

The proximity of companies or establishments that own animals or handle animal products unregulated can be considered to be a risk to poultry production because this influences transmission of S. enterica to the epidemiological units through the transit of animals and people. A study developed in France showed that the risk of Salmonella contamination on farms increased when feed trucks were parked near the entrance to the poultry sheds. It was shown that contamination of vehicles and footwear was a source of Salmonella infection in poultry farms. Thus, mechanical dissemination of microorganisms by vehicles and on the footwear of people who are traveling in the vicinity can give rise to a risk of Salmonella positivity in broilers (ROSE et al., 1999). However, in this study, most of the nearby epidemiological units were negative, thus suggesting that this parameter did not have any influence. Although these establishments were not evaluated for the presence of Salmonella, it was expected that proximity to them would favor infection, considering the flow of animals and people from places with questionable practices around the epidemiological units studied.

One of the main risk factors associated with S. enterica infection in poultry farms is the poultry density (ELGROUD et al., 2009), since the excretion of the bacteria by affected birds can infect the whole batch and even nearby batches without any presence of apparent clinical signs (PEREIRA et al., 1999). Among laying hens, batch size was also considered to be a major risk factor for $S$. enterica infection (HUNEAU-SALAÜN et al., 2009).

In the bivariate analysis of factors associated with Salmonella, the variables with significant p-values were the following: (1) presence or absence of other animals, contact with dairy cattle, contact with fish and contact with donkeys; (2) presence of agricultural stores, cold-storage facilities, agro-industrial cooperatives, risk-posing establishments and supermarkets; and (3) total housing capacity, average number of birds per poultry shed, number of surrounding poultry sheds, presence of breeding birds and presence of laying hens. Some logistic regression models were obtained from these variables, but in the final model only the average number of birds per poultry shed (30,501 to 32,500 [ref. $\leq 30,500$ ]), surrounding the presence of risk-posing establishments (yes [ref. no.]) and number of surrounding poultry sheds (above 5 [ref. 0 to 2]) were retained. This information can be considered to form a part of the Salmonella control strategy, through epidemiological surveillance inside and around the poultry sheds.

Geoprocessing has been used in epidemiological studies for spatial localization of disease cases, environmental correlations and analysis on distance variables, with the aim of obtaining information about and controlling these diseases (LÚCIO et al., 2018). In the distance analysis among the epidemiological units studied, it was noticed that the positive epidemiological units had lower means and ranges of distances than the negative units, thus allowing the hypothesis that they had greater potential for transmission of S. enterica. This parameter presented statistical difference according to the Mann-Whitney test $(\mathrm{p}<0.05)$ (Table 5$)$. Considering only the positive epidemiological units, most of them were within $5 \mathrm{~km}$ of other positive ones. Geographical proximity between epidemiological units may allow a hypothesis of favored dissemination of the agent (NAMATA et al., 2009), which could occur through the air or by means of vehicles, vectors, people, etc. In this light, it would be appropriate for new epidemiological units to be constructed at distances of more than $5 \mathrm{~km}$ from each other. The distance to the nearest epidemiological unit is a factor that can interact with the poultry density, because the greater the proximity is, the greater the size of the population at risk is (SNOW et al., 2010). In this study, it was observed that the positive epidemiological units were close to the negative ones, which suggested that the potential for transmission of S. enterica existed. Proximity to the town hall of the municipality and to highways might indicate greater flow of vehicles and proximity to rivers might indicate agglomerations of other animal species, especially wild birds, which could represent risk factors for S. enterica infection in broilers. Nonetheless, it was found that there were no statistical differences in relation to these parameters, thus suggesting that they did not have any influence on the presence of $S$. enterica in this study.

The HDI measures the living conditions of a population in terms of social and economic aspects. It was created by the United Nations Development Program (UNDP) in the 1980s. This index encompasses factors such as health, education and income. The municipal HDI measures the same parameters, but reflect the particularities of each municipality. It can range from zero to one, such that the level of human development is greater when the index is closer to one (CHEDIEK et al., 2013). The evaluation among the municipalities studied showed that the positive and negative epidemiological units were located predominantly in municipalities with high HDI. Worse HDI conditions could be expected to influence 
aspects of the education of people involved in poultry work and thus could favor Salmonella infection in epidemiological units through inappropriate management practices, for example.

Environmental factors are closely related to the results obtained from poultry production. In situations of temperatures lower than recommended, poultry initially reduce their food consumption and energy mobilization reserves for thermogenesis, which negatively influences their performance. On the other hand, increasing ambient temperatures due to climatic variations and use of different types of poultry shed are one of the most important issues in Brazilian poultry productivity. This may alter the functioning of the immune system, decrease resistance to infections and impair bird performance (QUINTEIRO-FILHO et al., 2010). In these situations, several negative physiological effects are observed, especially in the immune system, thus increasing the susceptibility to opportunistic diseases.

The combination of caloric stress and $S$. Enteritidis infection can disrupt the intestinal barrier of poultry. This allows the migration of bacteria through the intestinal mucosa to other organs and can also cause intestinal inflammation, thus reducing performance parameters (QUINTEIRO-FILHO et al., 2012). In this study, the temperature parameter showed little variation between positive and negative, and there was no statistical difference $(\mathrm{p}>0.05)$ according to the Mann-Whitney test (Table 7). This suggests that this variable was not related to S. enterica infection in the present analysis. Although no statistical differences regarding the temperatures in the municipalities were observed in this study, it is valid to consider that oscillations can occur during the year. However, this did not necessarily influence the average values used in this analysis.

It has been emphasized that studying climatic variables is important, especially within the field of bioclimatology (SANTOS et al., 2014). For production birds, it is possible to establish the geographical areas that are favorable for them, and those in which structural adjustments are required in order to provide thermal comfort for them. This is enabled through knowledge of the environmental needs of birds and the climatic conditions of the region. In a study evaluating risk factors for Campylobacter infection, it was found that high frequencies and volumes of the rain associated with temperature elevation increased the possibility of occurrence of this microorganism in broilers (JONSSON et al., 2012). However, the precipitation parameter in this study, as shown in Table 7, did not any present statistical difference according to the Mann-Whitney test ( $\mathrm{p}>0.05$ ), thus suggesting that it did not have any relationship with S. enterica infection.

The altitude can influence the air temperature and this relationship is especially important in tropical and subtropical regions, where altitude differences cause changes in climate, soil, vegetation and, consequently, the plants and animals' physiological processes (FRITZSONS et al., 2016). High altitudes have been shown to make temperature changes problematic because according to the characteristics of the location, increases in relative air humidity indexes may adversely affect exchanges and result in higher values for comfort parameters, like the temperature and humidity index (ITU) (KARKOW, 2015). Results from a meta-analysis showed that higher altitude is related to lower weight gain and higher mortality among broilers, regardless of sex and age at slaughter. In this study, it was observed that the municipalities with epidemiological units that were positive for $S$. enterica were at higher altitudes than those with negative epidemiological units $(\mathrm{p}<0.05)$.

It was found through this study that positivity for S. enterica in the epidemiological units studied was unrelated to the presence of animal species other than poultry. Moreover, most positive units did not have any presence of other animals. This can be attributed to the low competitiveness of Salmonella in the presence of other microorganisms, which prevented isolation. Alternatively, there may really has been no causal relationship. It was also observed that higher poultry density in the facilities may influence positivity for Salmonella. However, the poultry density in the surroundings did not present any statistical difference between positive and negative epidemiological units. Visually, the regions with the highest concentration of positive cases were located in the northwestern and western regions of the state. It was found that high altitude appeared to influence $S$. enterica positivity.

Based on the results reported in this paper, it is important to draw attention to some limitations to this study regarding Salmonella control. There were difficulties at the time of data collection for this study, especially regarding changes to the registration information among producers, which changed through transfers of epidemiological units between family members. There was also an absence of animal transit guide (ATG) information, which would have enabled analysis on the length of time for which sheds remained empty for sanitation measures between batches, to determine whether there might have been any relationship between this parameter and Salmonella positivity. Data regarding the age of the broilers at the time of collection of drag swabs and data on their vaccination status could also have provided information about the particularities of isolation and the serovars involved. Information regarding the general handling measures used in these epidemiological units would have also contributed to the results from this study. Such information could be obtained if there were a biosafety checklist, thus allowing classification and profiling of these establishments. The lack of serotyping of all results was also a limitation because if all the results had indicated the serovars involved it would have been possible to ascertain the characteristics and particularities of these serovars. 
It can be expected that in registered establishments, there will be a lower likelihood of $S$. enterica infection, considering all the biosafety measures that are adopted and the greater epidemiological surveillance that is implemented in these places than in unregistered establishments. As previously stated, the data made available for this study referred only to epidemiological units that were not registered at the time of sample collection. This is a limitation that prevented comparison between registered and unregistered epidemiological units. It is worth mentioning that the Brazilian government has encouraged the registration of commercial establishments through Normative Instruction No. 8 of February 17, 2017, which determined that commercial poultry establishments would be under an obligation to obtain registration within 365 days, among other measures (BRAZIL, 2017).

\section{CONCLUSIONS}

Considering that Salmonella serovars prevalence varies depending on the geographic location and time, factors related to the introduction and dissemination of these agents in poultry sheds are important for the adoption of effective control measures.

Based on the results of this study, it was found that a higher density broiler in poultry sheds, presence of surrounding poultry sheds, proximity between positive and negative epidemiological units and altitude of the municipality may be related to presence for S. enterica.

The information obtained in this study points to some factors related to positivity for S. enterica and reinforces the importance of serotyping to obtain other epidemiological data.

\section{AUTHORS' CONTRIBUTIONS}

Conceptualization: Santin, E. Data curation: Silva, N. D.; Laurindo, E. E. Formal analysis: Silva, N. D.; Laurindo, E. E.; Martins, C. M. Investigation: Silva, N. D.; Martins, C. M.; Silveira, R. M.; Silveira, C. T. Validation: Santin, E. Writing - original draft: Silva, N. D.; Santin, E. Writing - review \& editing: Silva, N. D.; Santin, E.

AVAILABILITY OF DATA AND MATERIAL

Not applicable.

FUNDING

There was no source of funding for this study.

\section{CONFLICTS OF INTEREST}

The authors declare that this study was conducted without any commercial or financial relationships that could be construed as a potential conflict of interest.

ETHICAL APPROVAL

Not applicable.

\section{ACKNOWLEDGEMENTS}

This study was made possible through support from the Ministério da Agricultura, Pecuária e Abastecimento (MAPA) and the Agência de Defesa Agropecuária do Paraná (ADAPAR), which provided data and directed the analyses.

\section{REFERENCES}

ABPA - ASSOCIAÇÃO BRASILEIRA DE PROTEÍNA ANIMAL. Relatório Anual 2020. São Paulo: ABPA, 2020. Available from: https:// abpa-br.org/wp-content/uploads/2020/05/abpa_relatorio_anual_2020_portugues_web.pdf. Access on: 11 May. 2020.

AGRITEMPO - Sistema de Monitoramento Agrometeorológico. Meterological station. Available at: https://www.agritempo.gov.br/ agritempo/jsp/Estatisticas/index.jsp?siglaUF=PR. Access on: 25 May 2019. 
ARAGON, T.J.; FAY, M.P.; WOLLSCHLAEGER, D.; OMIDPANAH, A. epitools: Epidemiology Tools. Version 0.5-10.1. CRAN, 2020. Available from: https://CRAN.R-project.org/package=epitools. Access on: 11 May 2020.

ARNOLD, M.E.; COOK, A.; DAVIES, R. A modelling approach to estimate the sensitivity of pooled faecal samples for isolation of Salmonella in pigs. Journal of the Royal Society Interface, Glasgow, v.2, n.4, p.365-372, 2005. https://doi.org/10.1098/rsif.2005.0057

BARROW, P.A. The paratyphoid salmonellae. Revue scientifique et technique - Office international des épizooties, v.19, n.2, p.351-75, 2000. https://doi.org/10.20506/rst.19.2.1225

BARROW, P.A.; FREITAS NETO, O.C. Pullorum disease and fowl typhoid-new thoughts on old diseases: A review. Avian Pathology, United Kingdom, v.40, n.1, p.1-13, 2011. https://doi.org/10.1080/03079457.2010.542575

BONI, H.F.K.; CARRIJO, A.S.; FASCINA, V.B. Ocorrência de Salmonella spp. em aviários e abatedouro de frangos de corte na região central de Mato Grosso do Sul. Revista Brasileira de Saúde e Produção Animal, Salvador, v.12, n.1, p.84-95, 2011. Available from: https:// www.bvs-vet.org.br/vetindex/periodicos/revista-brasileira-de-saude-e-producao-animal/12-(2011)-1/ocorrencia-de-salmonella-sppem-aviarios-e-abatedouro-de-frangos-de-co/. Access on: 20 Aug. 2020.

BOUWKNEGT, M.; VAN DE GIESSEN, A.W.; DAM-DEISZ, W.D.C.; HAVELAAR, A.H.; NAGELKERKE, N.J.D.; HENKEN, A.M. Risk factors for the presence of Campylobacter spp. in Dutch broiler flocks. Preventive Veterinary Medicine, Berlin, v.62, n.1, p.35-49, 2004. https://doi.org/10.1016/j.prevetmed.2003.09.003

BRAZIL. Ministério da Agricultura, Pecuária e Abastecimento. Instrução Normativa nº 78, de 3 de novembro de 2003. Aprovar as Normas Técnicas para Controle e Certificação de Núcleos e Estabelecimentos Avícolas como livres de Salmonella Gallinarum e de Salmonella Pullorum e Livres ou Controlados para Salmonella Enteritidis e para Salmonella Typhimurium. Brasília: Diário Oficial da União, 2003. Available from: https://www.gov.br/agricultura/pt-br/assuntos/sanidade-animal-e-vegetal/saude-animal/programas-de-saude-animal/ pnsa/imagens/INSTRUONORMATIVAN78DE3DENOVEMBRODE2003.pdf/view. Access on: 08 Dec. 2018.

BRAZIL. Ministério da Agricultura, Pecuária e Abastecimento. Instrução Normativa n 56, de 04 de dezembro de 2007. Estabelecer os procedimentos para registro, fiscalização e controle de estabelecimentos avícolas de reprodução e comerciais. Brasília: Diário Oficial da União, 2007. Available from: http://sistemasweb.agricultura.gov.br/sislegis/action/detalhaAto.do?method=visualizarAtoPortalMapa\&c have $=1152449158$. Access on: 08 Dec. 2018.

BRAZIL. Ministério da Agricultura, Pecuária e Abastecimento. Instrução Normativa no 10, de 11 de abril de 2013. Definir o programa de gestão de risco diferenciado, baseado em vigilância epidemiológica e adoção de vacinas, para os estabelecimentos avícolas considerados de maior susceptibilidade à introdução e disseminação de agentes patogênicos no plantel avícola nacional e para estabelecimentos avícolas que exerçam atividades que necessitam de maior rigor sanitário. Brasília: Diário Oficial da União, 2013. Available from: https://www.gov.br/agricultura/pt-br/assuntos/sanidade-animal-e-vegetal/saude-animal/programas-de-saude-animal/pnsa/imagens/ copy_of_INSTRUONORMATIVAN10DE11DEABRILDE2013.pdf. Access on: 08 Dec. 2018.

BRAZIL. Ministério da Agricultura, Pecuária e Abastecimento. Instrução Normativa n 20, de 21 de outubro de 2016. Ficam estabelecidos o controle e o monitoramento de Salmonella spp. nos estabelecimentos avícolas comerciais de frangos e perus de corte e nos estabelecimentos de abate de frangos, galinhas, perus de corte e reprodução, registrados no Serviço de Inspeção Federal (SIF), com objetivo de reduzir a prevalência desse agente e estabelecer um nível adequado de proteção ao consumidor. Brasília: Diário Oficial da União, 2016. Available from: https://www.gov.br/agricultura/pt-br/assuntos/sanidade-animal-e-vegetal/saude-animal/programas-de-saude-animal/pnsa/imagens/ INSTRUONORMATIVAN20DE21DEOUTUBRODE2016.pdf. Access on: 08 Dec. 2018.

BRAZIL. Ministério da Agricultura, Pecuária e Abastecimento. Portaria no 193, de 19 de setembro de 1994. Instituir o Programa Nacional de Sanidade Avícola no âmbito da Secretaria de Defesa Agropecuária - SDA, envolvendo o Departamento de Defesa Animal - DDA e Departamento de Inspeção de Produtos de Origem Animal - DIPOA. Brasília: Diário Oficial da União, 1994. Available from: https://www.emdagro.se.gov.br/wp-content/uploads/2020/06/PORTARIA-193-DE-19-DE-SETEMBRO-DE-1994. pdf. Access on: 08 Dec. 2018.

BRENNER, F.W.; VILLAR, R.G.; ANGULO, F.J.; TAUXE, R.; SWAMINATHAN, B. Salmonella Nomenclature. Journal of Clinical Microbiology, Boston, v.38, n.7, p.2465-2467, 2000. https://doi.org/10.1128/JCM.38.7.2465-2467.2000 
PROGRAMA DAS NAÇÕES UNIDAS PARA O DESENVOLVIMENTO (PNUD); INSTITUTO DE PESQUISA ECONÔMICA APLICADA (IPEA); FUNDAÇÃO JOÃO PINHEIRO (FJP). O Índice de Desenvolvimento Humano Municipal Brasileiro. Brasília: PNUD, 2013. Available from: https://www.ipea.gov.br/portal/index.php?option=com_content\&id=19153. Access on: 30 Oct. 2018.

DERACHE, C.; ESNAULT, E.; BONSERGENT, C.; LE VERN, Y.; QUÉRÉ, P., LALMANACH, A.-C. Differential modulation of $\beta$-defensin gene expression by Salmonella Enteritidis in intestinal epithelial cells from resistant and susceptible chicken inbred lines. Developmental \& Comparative Immunology, Uppsala, v.33, n.9, p.959-966, 2009. https://doi.org/10.1016/j.dci.2009.03.005

ELGROUD, R.; ZERDOUMI, F.; BENAZZOUZ, M.; BOUZITOUNA-BENTCHOUALA, C.; GRANIER, S.A.; FRÉMY, S.; BRISABOIS, A.; DUFOUR, B.; MILLEMANN, Y. Characteristics of Salmonella Contamination of Broilers and Slaughterhouses in the Region of Constantine (Algeria). Zoonoses and Public Health, Minnesota, v.56, n.2, p.84-93, 2009. https://doi.org/10.1111/j.1863-2378.2008.01164.x

Environmental Systems Research Institute (ESRI). ArcGIS . Version 10.5.1. West Redlands: ESRI, 2017.

EUROPEAN FOOD SAFETY AUTHORITY (EFSA); EUROPEAN CENTRE FOR DISEASE PREVENTION AND CONTROL (ECDC). The European Union Summary Report on Trends and Sources of Zoonoses, Zoonotic Agents and Food-Borne Outbreaks in 2012. EFSA Journal, v.12, n.12, p.3547, 2014. https://doi.org/10.2903/j.efsa.2014.3547

EUROPEAN FOOD SAFETY AUTHORITY (EFSA); EUROPEAN CENTRE FOR DISEASE PREVENTION AND CONTROL (ECDC). The European Union summary report on trends and sources of zoonoses, zoonotic agents and food-borne outbreaks in 2017. EFSA Journal, v.16, n.12, p.262, 2018. https://doi.org/10.2903/j.efsa.2018.5500

FRITZSONS, E.; MANTOVANI, L.E.; WREGE, M.S. Relação entre altitude e temperatura: Uma contribuição ao zoneamento climático no estado de Santa Catarina, Brasil. Revista Brasileira de Climatologia, Curitiba, v.18, p.80-92, 2016. https://doi.org/10.5380/abclima. v18i0.39471

GAST, R.K.; BENSON, S.T. The Comparative Virulence for Chicks of Salmonella enteritidis Phage Type 4 Isolates and Isolates of Phage Types Commonly Found in Poultry in the United States. Avian Diseases, Jacksonville, v.39, n.3, p.567-574, 1995. https://doi.org/10.2307/1591810

GRIMONT, P. A. D.; WEILL, F. X. Antigenic formulae of the Salmonella serovars. 9th. ed. Paris: WHO; Institut Pasteur, 2007. Available from: https://www.pasteur.fr/sites/default/files/veng_0.pdf. Access on: 21 Sept. 2018.

HUMPHREY, T. Salmonella, stress responses and food safety. Nature Reviews Microbiology, London, v.2, n.6, p.504-509, 2004. https:// doi.org/10.1038/nrmicro907

HUNEAU-SALAÜN, A.; CHEMALY, M.; LE BOUQUIN, S.; LALANDE, F.; PETETIN, I.; ROUXEL, S.; MICHEL, V.; FRAVALO, P.; ROSE, N. Risk factors for Salmonella enterica subsp. enterica contamination in 519 French laying hen flocks at the end of the laying period. Preventive Veterinary Medicine, Berlin, v.89, n.1-2, p.51-58, 2009. https://doi.org/10.1016/j.prevetmed.2009.01.006

IBM CORP. IBM SPSS Statistics for Windows. Version 21.0. Armonk: IBM Corp, 2012. Available from: https://www.ibm.com/support/ pages/spss-statistics-210-available-download. Access on: 12 July 2018.

JONSSON, M.E.; CHRIÉL, M.; NORSTRÖM, M.; HOFSHAGEN, M. Effect of climate and farm environment on Campylobacter spp. colonisation in Norwegian broiler flocks. Preventive Veterinary Medicine, Berlin, v.107, n.1-2, p.95-104, 2012. https://doi.org/10.1016/j. prevetmed.2012.05.002

KARKOW, A.K. Perdas produtivas em frangos de corte devido a variações de temperatura, umidade e altitude no Rio Grande do Sul. 2015. Dissertation (doctoral dissertation in Zootechny) - Universidade Federal de Santa Maria, Santa Maria, 2015. Available from: https:// repositorio.ufsm.br/bitstream/handle/1/4370/KARKOWcANAKATIA.pdf?sequence=1\&isAllowed=y. Access on: 13 Dec. 2018.

LE BOUQUIN, S.; ALLAIN, V.; ROUXEL, S.; PETETIN, I.; PICHEROT, M.; MICHEL, V.; CHEMALY, M. Prevalence and risk factors for Salmonella spp. contamination in French broiler-chicken flocks at the end of the rearing period. Preventive Veterinary Medicine, Berlin, v.97, n.3-4, p.245-251, 2010. https://doi.org/10.1016/j.prevetmed.2010.09.014 
LÚCIO, É.C.; BORGES, J. de M.; BATISTA FILHO, A.F.B.; GOUVEIA, G.V.; COSTA, M.M. da; MOTA, R.A.; PINHEIRO JUNIOR, J.W. Ocorrência de ovinos portadores da infecção por Campylobacter spp. no estado de Pernambuco. Pesquisa Veterinária Brasileira, Porto Alegre, v.38, n.2, p.262-270, 2018. https://doi.org/10.1590/1678-5150-pvb-4895

MARÍN, C.; BALASCH, S.; VEGA, S.; LAINEZ, M. Sources of Salmonella contamination during broiler production in Eastern Spain. Preventive Veterinary Medicine, Berlin, v.98, n.1, p.39-45, 2011. https://doi.org/10.1016/j.prevetmed.2010.09.006

NAMATA, H.; WELBY, S.; AERTS, M.; FAES, C.; ABRAHANTES, J.C.; IMBERECHTS, H.; VERMEERSCH, K.; HOOYBERGHS, J.; MÉROC, E.; MINTIENS, K. Identification of risk factors for the prevalence and persistence of Salmonella in Belgian broiler chicken flocks. Preventive Veterinary Medicine, Berlin, v.90, n.3-4, p.211-222, 2009. https://doi.org/10.1016/j.prevetmed.2009.03.006

OLIVEIRA, N.F. de; SANTANA, V.S.; LOPES, A.A. Razões de proporções e uso do método delta para intervalos de confiança em regressão logística. Revista de Saúde Pública, São Paulo, v.31, n.1, p.90-99, 1997. https://doi.org/10.1590/S0034-89101997000100012

PANDINI, J.A.; PINTO, F.G. da S.; MULLER, J.M.; WEBER, L.D.; MOURA, A.C. de. Ocorrência e perfil de resistencia antimicrobiana de sorotipos de Salmonella spp. isolados de aviários do Paraná, Brasil. Arquivos do Instituto Biológico, São Paulo, v.82, p.1-6, 2015. https:// doi.org/10.1590/1808-1657000352013

PARANÁ. Secretaria da Agricultura e Abastecimento. Portaria no 290, de 09 de novembro de 2017. Aprova o procedimento para a emissão da Certidão de Registro de Estabelecimentos Avícolas de Produção Comercial. Curitiba, ADAPAR, 2017. Available from: https://www. adapar.pr.gov.br/sites/adapar/arquivos_restritos/files/documento/2020-10/300_17.pdf. Access on: 13 Dec. 2018.

PEREIRA, V.L. de A.; SILVA, G.M. da; LEMOS, M. Presença de Salmonella em frangos de corte aparentemente sadios em unidades de criação industrial na região de São José do Vale do Rio Preto - RJ. Revista Brasileira de Ciência Veterinária, Niterói, v.6, n.3, p.156-161, 1999. https://doi.org/10.4322/rbcv.2015.158

PULIDO-LANDÍNEZ, M. Food safety - Salmonella update in broilers. Animal Feed Science and Technology, Thessaloniki, v.250, p.53-58, 2019. https://doi.org/10.1016/j.anifeedsci.2019.01.008

QUINTEIRO-FILHO, W.M.; GOMES, A.V.S.; PINHEIRO, M.L.; RIBEIRO, A.; FERRAZ-DE-PAULA, V.; ASTOLFI-FERREIRA, C.S.; FERREIRA, A.J.P.; PALERMO-NETO, J. Heat stress impairs performance and induces intestinal inflammation in broiler chickens infected with Salmonella Enteritidis. Avian Pathology, United Kingdom, v.41, n.5, p.421-427, 2012. https://doi.org/10.1080/03079457.2012.709315

QUINTEIRO-FILHO, W.M.; RIBEIRO, A.; FERRAZ-DE-PAULA, V.; PINHEIRO, M.L.; SAKAI, M.; SÁ, L.R.M.; FERREIRA, A.J.P.; PALERMO-NETO, J. Heat stress impairs performance parameters, induces intestinal injury, and decreases macrophage activity in broiler chickens. Poultry Science, Morgantown, v.89, n.9, p.1905-1914, 2010. https://doi.org/10.3382/ps.2010-00812

R CORE TEAM (2019). R: A language and environment for statistical computing. R Foundation for Statistical Computing, Vienna, Austria.URL https://www.R-project.org/.

ROSE, N.; BEAUDEAU, F.; DROUIN, P.; TOUX, J.Y.; ROSE, V.; COLIN, P. Risk factors for Salmonella enterica subsp. enterica contamination in French broiler-chicken flocks at the end of the rearing period. Preventive veterinary medicine, Berlin, v.39, n.4, p.265-277, 1999. https:// doi.org/10.1016/S0167-5877(99)00002-1

SANTOS, G. de B.; SOUSA, I.F. de; BRITO, C.O.; SANTOS, V. da S.; BARBOSA, R. de J.; SOARES, C. Estudo bioclimático das regiões litorânea, agreste e semiárida do estado de Sergipe para a avicultura de corte e postura. Ciência Rural, Santa Maria, v.44, n.1, p.123-128, 2014. https://doi.org/10.1590/S0103-84782013005000148

SÃO PAULO. Secretaria de Agricultura e Abastecimento; Coordenadoria de Defesa Agropecuária. Portaria n ${ }^{\circ} 126$, de 03 de novembro de 1995. Aprovar as "Normas de Credenciamento e Monitoramento de Laboratórios de Diagnóstico das Salmoneloses Aviárias (S. Enteritidis, S. Gallinarum, S. Pullorum e S. Typhimurium)”. São Paulo: Diário Oficial da União, 1995. Available from: https://www.defesa.agricultura. sp.gov.br/legislacoes/portaria-sda-126-de-03-11-1995,372.html. Access on: 13 Dec. 2018.

SHIVAPRASAD, H.L.; TIMONEY, J.F.; MORALES, S.; LUCIO, B.; BAKER, R.C. Pathogenesis of Salmonella enteritidis Infection in Laying Chickens. I. Studies on Egg Transmission, Clinical Signs, Fecal Shedding, and Serologic Responses. Avian diseases, Jacksonville, v.34, n.3, p.548-557, 1990. https://doi.org/10.2307/1591243 
SILVEIRA, C.T.; SILVEIRA, R.M.P. Índice de posição topográfica (IPT) para classificação geomorfométrica das formas de relevo no estado do Paraná - Brasil. Revista Rảe Ga - O Espaço Geográfico em Análise, Curitiba, v.41, p.98-130, 2017. https://doi.org/10.5380/ raega.v41i0.51674

SNOW, L.C.; DAVIES, R.H.; CHRISTIANSEN, K.H.; CARRIQUE-MAS, J.J.; COOK, A.J.C.; EVANS, S.J. Investigation of risk factors for Salmonella on commercial egg-laying farms in Great Britain, 2004-2005. Veterinary Record, London, v.166, n.19, p.579-586, 2010. https://doi.org/10.1136/vr.b4801

TACK, D.M. et al. Preliminary Incidence and Trends of Infections with Pathogens Transmitted Commonly Through Food — Foodborne Diseases Active Surveillance Network, 10 U.S. Sites, 2015-2018. Morbidity and Mortality Weekly Report, Atlanta, v.68, n.16, p.369-373, 2019. https://doi.org/10.15585/mmwr.mm6816a2

VOSS-RECH, D.; VAZ, C.L.S.; ALVES, L.; COLDEBELLA, A.; LEÃO, J.A.; RODRIGUES, D.P.; BACK, A. A temporal study of Salmonella enterica serotypes from broiler farms in Brazil. Poultry Science, Morgantown, v.94, n.3, p.433-441, 2015. https://doi.org/10.3382/ps/peu081 